\title{
The role of spiritual beliefs in conserving wildlife species in religious shrines of Bangladesh
}

\author{
Sharif Ahmed Mukul ${ }^{\mathrm{ab} *}$, A.Z.M. Manzoor Rashid ${ }^{\mathrm{cd}}$ and Mohammad Belal Uddin ${ }^{\mathrm{d}}$ \\ ${ }^{a}$ School of Agriculture and Food Sciences, University of Queensland, Brisbane Qld 4072, Australia; ${ }^{b}$ Centre for Research on \\ Land-use Sustainability, Maijdi 3800, Noakhali, Bangladesh; ' Environmental Law, School of Law, University of Western \\ Sydney, Sydney, Australia; ${ }^{d}$ Department of Forestry and Environmental Science, School of Agriculture and Mineral Sciences, \\ Shahajalal University of Science and Technology, Sylhet 3114, Bangladesh
}

(Received 7 February 2012; final version received 15 May 2012)

\begin{abstract}
The conservation of biodiversity is developing into one of the biggest challenges of the century. Rapidly declining forests and the degradation of wild habitats are a direct result of a lack of public awareness and participation in the process of conservation. However, in small land areas in undeveloped countries characterised by high population density and poor public awareness, local religious and/or spiritual beliefs favour conservation of biodiversity at both species and habitat levels. This paper attempts to explore this practice based on case studies from Bangladesh where for generations some local beliefs have been protecting important wildlife species such as the Black Soft-shell Turtle, Mugger Crocodile, Rock Pigeon and Rhesus Macaque. The paper also offers a SWOT analysis of the potential role and challenges of these religious shrines as a refuge for biodiversity.
\end{abstract}

Keywords: shrine; Sufi; wildlife conservation; spiritual belief; Bangladesh

\section{Introduction}

The worship of nature and its living organisms has been a tradition of many world religions (Swamy, Kumar, and Sundarapandian 2003; Bhagwat and Rutte 2006) including Hinduism, Buddhism and most of the sub-religions (Anthwal, Sharma, and Sharma 2006) on the Indian subcontinent. Similarly, in Abrahamic religions, including Judaism, Christianity and Islam, in the 'Noah's Ark' narrative, according to the 'Book of Genesis', at God's command Noah built an ark to carry pairs of all the animals on Earth to protect them from an imminent flood. Although these religions do not worship creation as such, conservation ethics is deeply ingrained in them. There is quite a bit of evidence indicating that religious and/or spiritual appreciation positively contributes to conservation, both at the species and landscape level (Khan, Menon, and Bawa 1997; Berkes 1999; Devereux 2000; Swamy, Kumar, and Sundarapandian 2003).

Bangladesh, a densely populated (955 people/ square $\mathrm{km}$ ) country with no committed focus on conservation until the late 1980s, is endowed with a rich variety of biodiversity, mainly due to its unique geo-climatic location (Appanah and Ratnam 1992). The country also has one of the lowest per capita ratios of land designated for conservation, a total of 242,596 hectares of land under the protected area management system (WRI 2009). Under such circumstances, the conservation of biodiversity, especially wildlife, is crucial since they are highly sensitive to habitat loss and environmental degradation. The continual shrinkage of forests and high rate of deforestation $(0.3 \%$ per year between 1990 and 2005) perpetuated by the poor socio-economic context challenges the governmental efforts to combat a quickly eroding biodiversity (FAO 2005; Mukul and Quazi 2009). However, in some of the religious shrines of Bangladesh (widely popular as 'majar' or 'dargah') several wildlife species have long been protected and conserved in proximity to the shrines (Ahsan, Haque, and Fugler 1991). The present paper aims to explore the role of religious and/or spiritual beliefs in selected shrines in conserving biodiversity, chiefly at the species level, with additional emphasis on their status, opportunities and limitations. We believe this study will be beneficial to revise the role played by such beliefs in conserving biodiversity, and will offer policy-makers a new tool for conservation planning, especially for regions where people still have great religious faith and where biodiversity conservation is a challenging task due to weak socio-economic and cultural standards.

\section{Methods}

Four specific religious shrines were chosen for the study. Table 1 illustrates the selected shrines and additional features associated with them. Information was collected through field visits at selected sites during

\footnotetext{
*Corresponding author. Email: s.mukul@uq.edu.au 
Table 1. List of studied shrines and their general attributes.

\begin{tabular}{lccc}
\hline Name of the shrine & Age of the shrine & Location & Area \\
\hline Shrine of Hz. Sayed Chasni Peer (R.) & $\sim 700$ & Sylhet & $\sim 7.5$ ha \\
Shrine of Khan-i-Azam Hz. Khan Jahan Ali (R.) & $\sim 600$ & Khulna & $\sim 15$ ha \\
Shrine of Shaikh Jalaluddin Hz. Shah Jalal (R.) & $\sim 700$ & Sylhet & $\sim 5$ ha \\
Shrine of Sultan-ul-Arefin Hz. Bayzid Bostami (R.) & $\sim 1200$ & Chittagong & $\sim 5$ ha \\
\hline
\end{tabular}

Table 2. Conservation status of the wildlife species and related information.

\begin{tabular}{|c|c|c|c|c|}
\hline \multirow{2}{*}{$\begin{array}{l}\text { Species (common, local and } \\
\text { Latin name) }\end{array}$} & \multirow{2}{*}{$\begin{array}{c}\text { Population } \\
\text { (within shrine) }\end{array}$} & \multicolumn{2}{|c|}{ Conservation status* } & \multirow[b]{2}{*}{ Distribution } \\
\hline & & Bangladesh status & Global status** & \\
\hline $\begin{array}{l}\text { Black Soft-shell Turtle, } \\
\text { Bostami Kachim, } \\
\text { Aspideretes nigricans }{ }^{* * *}\end{array}$ & $\sim 400$ & $\begin{array}{l}\text { Critically } \\
\text { Endangered (CE) }\end{array}$ & $\begin{array}{l}\text { Extinct in the } \\
\text { Wild (EW) }\end{array}$ & $\begin{array}{l}\text { Endemic } \\
\text { (also found in } \\
\text { Assam, India) }\end{array}$ \\
\hline $\begin{array}{l}\text { Mugger Crocodile/Broad- } \\
\text { snouted Crocodile, Kala } \\
\text { Pahar/Dhola Pahar, } \\
\text { Crocodylus palustris*** }\end{array}$ & 2 (deceased) & Extinct & Vulnerable (VU) & Asia \\
\hline $\begin{array}{l}\text { Rhesus Macaque, Banor, } \\
\text { Macaca mulatta }\end{array}$ & $\sim 150$ & Vulnerable (VU) & $\begin{array}{l}\text { Least } \\
\text { Concern (LC) }\end{array}$ & $\begin{array}{l}\text { Tropical Asia, } \\
\text { Africa and } \\
\text { South America }\end{array}$ \\
\hline $\begin{array}{l}\text { Rock Pigeon, Jalali Kobutor, } \\
\text { Columba livia }\end{array}$ & $\sim 3000$ & Data Deficient (DD) & $\begin{array}{l}\text { Least } \\
\quad \text { Concern (LC) }\end{array}$ & Global \\
\hline
\end{tabular}

*As per World Conservation Union; **as suggested at IUCN (2009); ***population of this species within country limited only to that shrine.

the year 2009. Both qualitative and quantitative data were collected and interviews were arranged involving responsible persons from Majar committees - formed locally to govern overall management of the site and nominated and/or elected by communities with the help of local administration. Data collected through field work was further verified and cross-checked by other reliable sources when required. The ages of the shrines were determined from available literature and references (e.g. 'Banglapedia'- the national encyclopedia of Bangladesh), as well as from any 'epitaph' available in the respective shrines. The number of visitors to each shrine was determined by observation as well as by discussion with members of the majar committee and with local elders.

\section{Results and discussion}

\section{Historical profile of the shrines}

Basically, the chosen shrines are memorial sites named after the Sufis associated with them. The Sufis were the great mystics of Islam, poets and philosophers whose objective was the reparation of the human heart, turning it away from all else but God (Zarruq, Istrabadi, and Hanson 2008). The history of the arrival of these Sufis on the Indian sub-continent goes back to ancient times and is accompanied by many myths and lore associated with their arrival, some quite contradictory. For example, in the history of the arrival of Sultan-ul-Arefin $\mathrm{Hz}$. Bayzid Bostami, locally it is believed that he was buried in the area but according to other sources he has never been in that region (Ahsan and Saeed 2009).

The arrival of the Sufis in this region was largely due to their intention to establish and preach Islam (ASB 2006). Their shrines are situated in Sylhet city, and are nearly 700 years old. Khan-i-Azam Hz. Khan Jahan Ali, an architect of that period, was originally from Turkey. His shrine is nearly 600 years old (ASB 2006). It is ironic that in some shrines the Sufis themselves are worshiped whereas as they fiercely objected to the worship of humans. Structurally, all of these shrines consist of a tomb, mosque and some permanent water body (pond), except in the case of the Shrine of Hz. Sayed Chasni Peer. The wildlife associated with each of these shrines is believed to have persisted since the lifetime of the respective Sufis.

\section{The wildlife species and their conservation status}

Table 2 shows the wildlife species, their population and local and international conservation status. Many of 


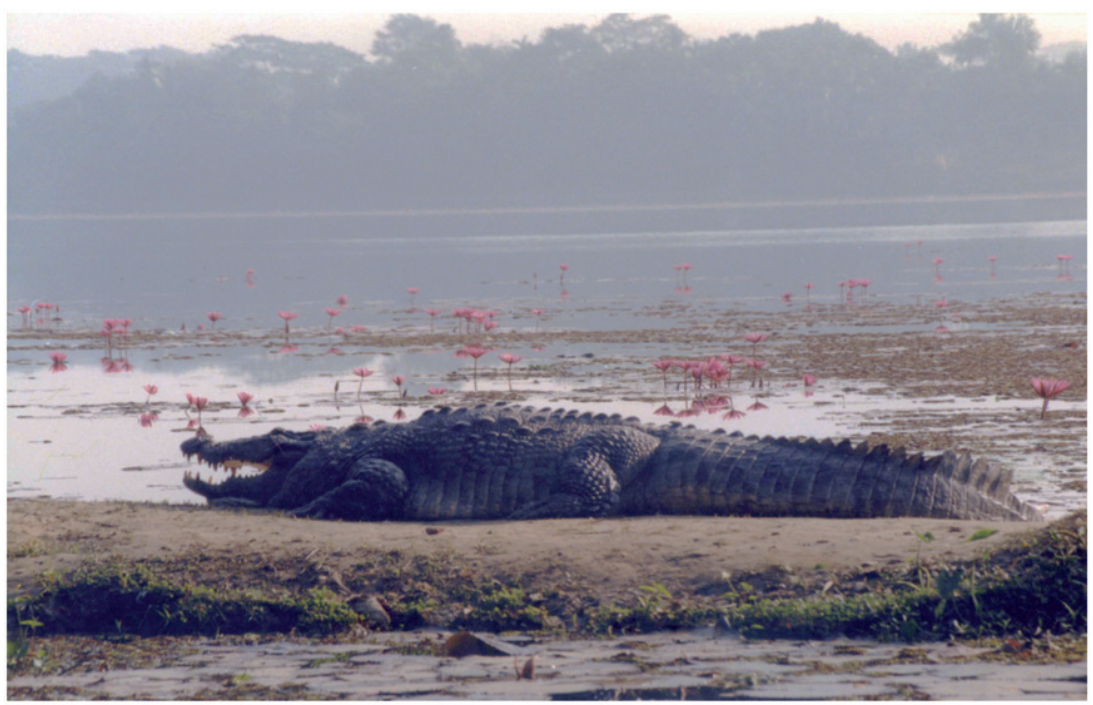

Figure 1. Mugger Crocodile in the Shrine of Hz. Khan Jahan Ali in Khulna. Photo credit: Monirul H. Khan.

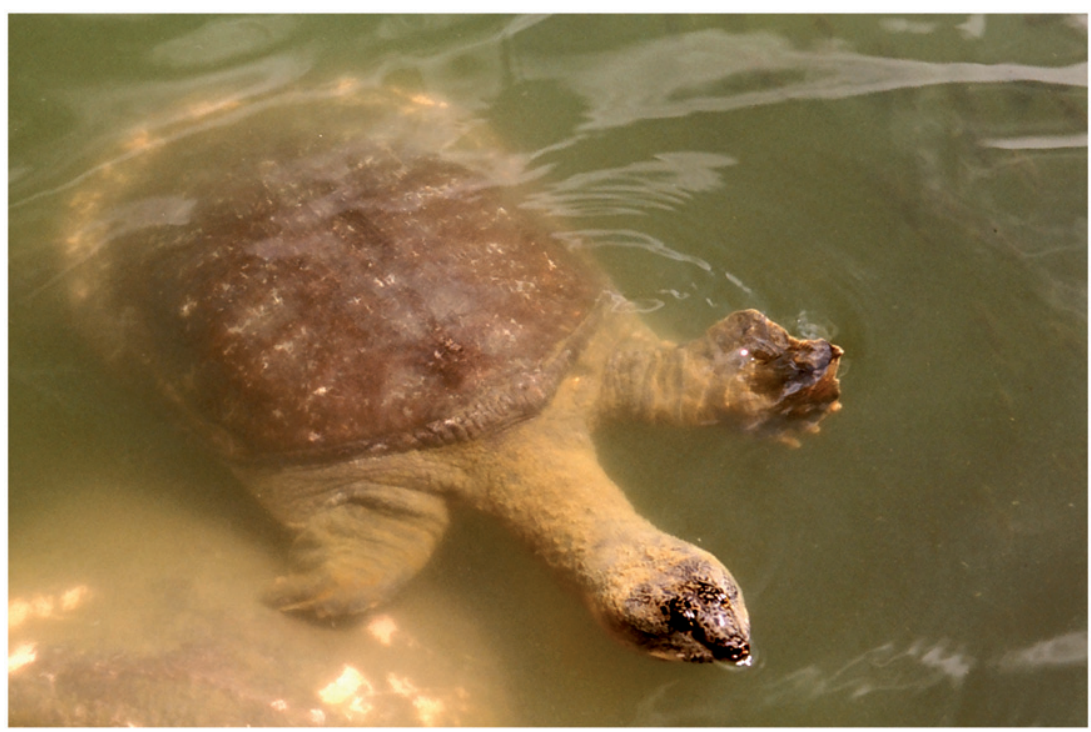

Figure 2. Black Soft-shell Turtle in the Shrine of Hz. Bayzid Bostami in Chittagong. Photo credit: Monirul H. Khan.

the associated species, such as the Two Broad-snouted Crocodile or Mugger (Figure 1), apparently have a lifespan much beyond those found outside the shrine areas. This species is believed to be extinct locally (Islam, Ameen, and Nishat 2000a). Among the other species, the Black Soft-shell Turtle (Figure 2) is critically endangered in Bangladesh whereas the Rhesus Macaque (Figure 3) has been reported to be vulnerable, although they are still abundant in natural forests of the country (Islam, Ameen, and Nishat 2000b). The population of Rock Pigeons (Figure 4) in the country has been reported to be in decline (Islam, Ameen, and Nishat 2000c).

\section{Myths and people's attitudes}

There are also quite a few contradictory myths about the wildlife existing in the shrines. For example, there is a strong belief about the Black Soft-shell Turtle (Bostami Kachim in Bengali) and their attachment to the shrine of Sultan-ul-Arefin Hz. Bayzid Bostami. There has been a tale for generations that these turtles were brought and introduced into the Bostami pond by the Sufi himself. The local belief on the other hand is that these turtles were once sinful men who came into association with the saint, who then changed them into turtles as punishment for their wickedness. There is another belief that these turtles were evil spirits and 


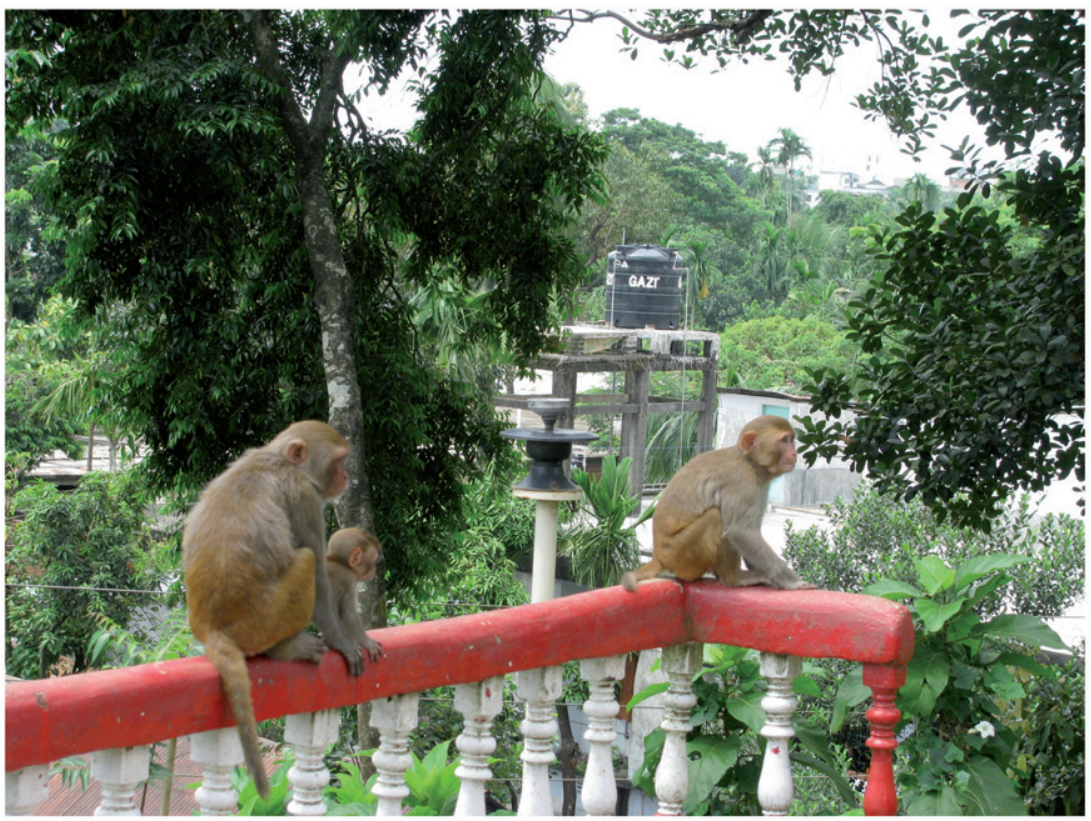

Figure 3. Rhesus Macaque in the Shrine of Hz. Sayed Chasni Peer in Sylhet. Photo credit: Sharif A. Mukul.

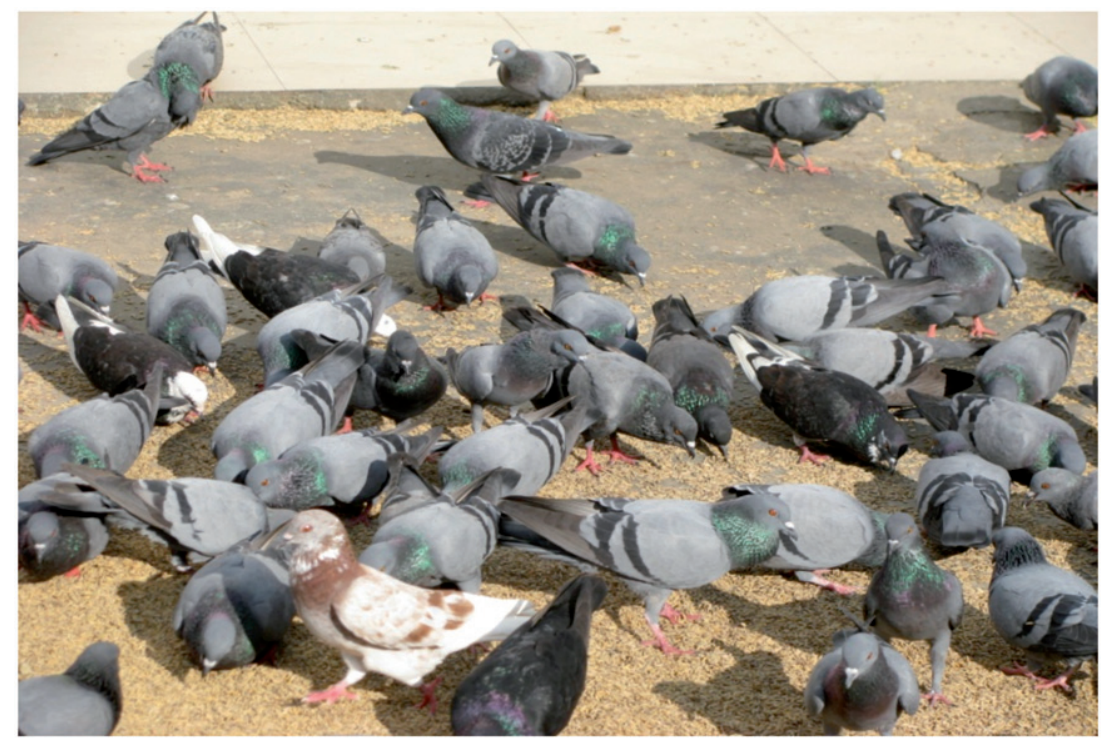

Figure 4. Rock Pigeons in the Shrine of Hz. Shah Jalal in Sylhet. Photo credit: Sharif A. Mukul.

were turned into the present form because they incurred the wrath of the Saint (Ahsan and Saeed 2009).

Table 3 presents the popular myths and beliefs linked to the wildlife species in the study of shrines. Most of these individual organisms are identified by local names, distinct from their common or Bengali names. For example, the Black Soft-shell Turtle in the shrine of Sultan-ul-Arefin Hz. Bayzid Bostami is locally called as 'Gadali-Madali', while the two last remaining
Mugger Crocodiles in the shrine of Khan-i-Azam Hz. Khan Jahan Ali (R.) are locally called 'Kala Pahar' and 'Dhola Pahar'.

It is revealed from the empirical study that a large number of visitors (Figure 5) from different religions pay visit to these shrines each day, which increase dramatically during the weekends and other public holidays. During the visits, the pilgrims and visitors also feed and cherish these wildlife species with the intention of gaining God's blessings. A handsome 
Table 3. Wildlife species, related myths and number of visitors in observed days.

\begin{tabular}{|c|c|c|c|}
\hline \multirow[b]{2}{*}{ Species } & \multicolumn{2}{|c|}{ Visitors (per day) } & \multirow[b]{2}{*}{ Myth and other history* } \\
\hline & Weekend & Regular day & \\
\hline Black Soft-shell Turtle & $\sim 2000$ & $\sim 750$ & $\begin{array}{l}\text { These turtles are believed to have been brought into the } \\
\text { pond by the Sufi himself; contradictorily, others } \\
\text { believe that the turtles were once people (evil spirits) } \\
\text { whom the Sufi cursed! }\end{array}$ \\
\hline Mugger Crocodile & $\sim 1500$ & $\sim 650$ & $\begin{array}{l}\text { Some followers of the Sufi released a few of these } \\
\text { crocodiles in his pond and he accepted them as pets. }\end{array}$ \\
\hline Rhesus Macaque & $\sim 650$ & $\sim 250$ & $\begin{array}{l}\text { Reliable data is unavailable; presumably since the area } \\
\text { was heavily forested before, the Sufi began to feed } \\
\text { some of these monkeys and they became his pets; his } \\
\text { followers continue to feed them with a mind to } \\
\text { eliciting favor from God. }\end{array}$ \\
\hline Rock Pigeon & $\sim 3500$ & $\sim 1750$ & $\begin{array}{l}\text { The Sultan of Delhi presented a pair of pigeons when he } \\
\text { met the Sufi, and the customary belief is that } \\
\text { shooting/eating of these pigeons brings bad luck. }\end{array}$ \\
\hline
\end{tabular}

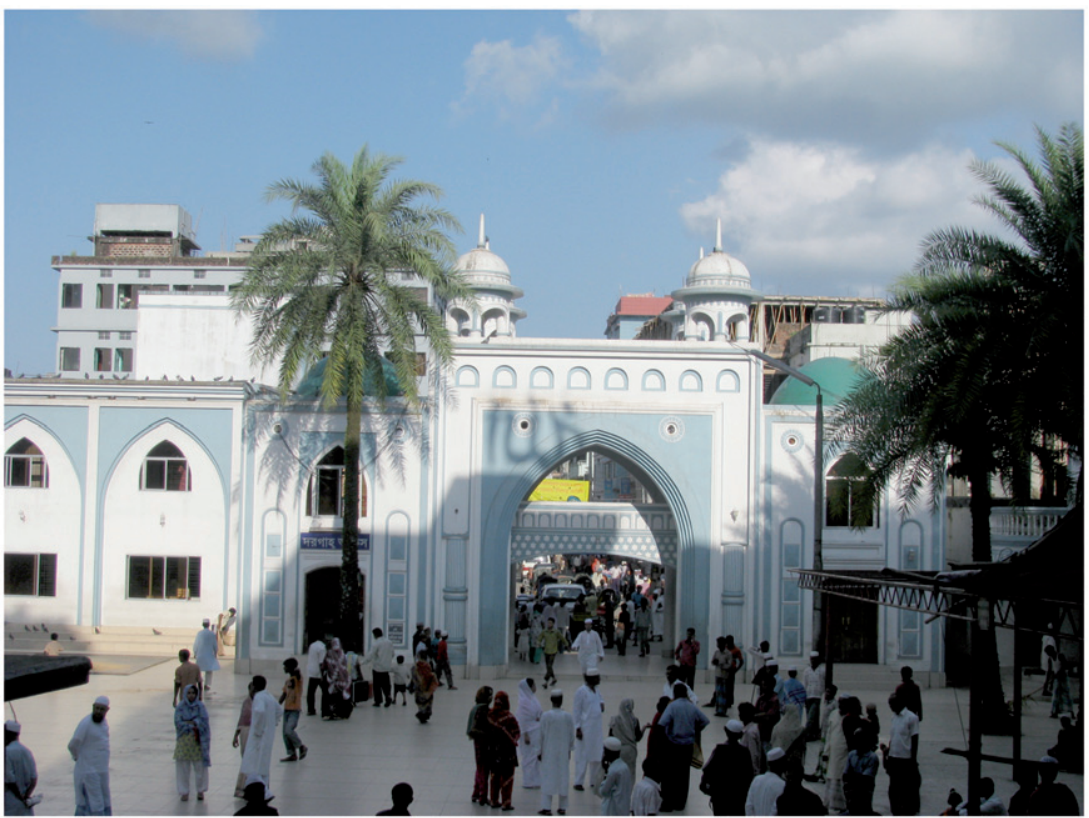

Figure 5. Visitors on a regular day at Shrine of $\mathrm{Hz}$. Shah Jalal in Sylhet. Photo credit: Sharif A. Mukul.

number of business enterprises have been established surrounding the shrines that mostly sell feed for these wildlife.

Based on fieldwork, a SWOT analysis was performed in the study shrines to determine their role, strengths and opportunities to serve as a refuge for these threatened wildlife (Table 4). The main strength and opportunity is that there is still a sustainable source of food and funds available in the studied shrines both from government and visitors that could potentially be used for the sustainable management of these animals. Local support is essential for conservation and due to the religious attachment to these shrine animals this support is readily available. The weaknesses identified are that the management of these animals has been done locally for ages by unskilled people and is not necessarily based in a scientific approach. Lack of technical skill in wildlife management, high disturbance rates, and excessive feeding by visitors often cause fungal infections and water pollution in the ponds. Also, physiological disorders can occur due to the accumulation of body fat that negatively affects fertilisation capacity. Furthermore, changing human beliefs due to 
Table 4. SWOT analysis of shrines and conservation value.

\begin{tabular}{|c|c|}
\hline Strengths & Weaknesses \\
\hline $\begin{array}{l}\text { 1. Conserve biodiversity at species level } \\
\text { 2. Adequate food and care } \\
\text { 3. Sustainability (funds, maintenance) }\end{array}$ & $\begin{array}{l}\text { 1. Unscientific management } \\
\text { 2. Overfeeding causes negative effects on fertility etc. } \\
\text { 3. Repeated disturbances by visitors }\end{array}$ \\
\hline Opportunities & Threats \\
\hline $\begin{array}{l}\text { 1. Alternative option for conserving biodiversity } \\
\text { 2. Local support } \\
\text { 3. Increased monitoring and care is possible } \\
\text { due to the financial efficacy }\end{array}$ & $\begin{array}{l}\text { 1. Changes in human belief } \\
\text { 2. Internal politics (for money, influence) in the management } \\
\text { 3. Fragile to any sudden changes in } \\
\text { environment/limited habitat area }\end{array}$ \\
\hline
\end{tabular}

modernisation and ever-shrinking habitats threaten the future of the wildlife species in the studied areas.

\section{Conclusions}

Apart from conserving wildlife some of these shrines seem to hold a high diversity of plants, particularly figs (Ficus spp.) that offer ideal habitats to birds, some herpetofauna and insects. The shrines also host certain orchids, liana and epiphytes and provide food for birds and small mammals. The Sufi shrines and the culture of peaceful coexistence with their wildlife could be an important tool to mobilise public support in favor of biodiversity conservation particularly in areas where biodiversity conservation is difficult due to socioeconomic and political fragility.

To ensure and enhance conservation in such religious shrines, governments should work together with local conservation agencies to promote the scientific management of remaining wildlife species. Restoration of wildlife habitats within and outside the shrines, regular monitoring of their populations, measuring the carrying capacity (i.e. number of allowable visitors per day), and regular training to the people involved in the day-to-day management of the wildlife species in the shrines will certainly help their sustainable conservation and development.

\section{Acknowledgements}

An earlier version of this paper was presented at Technische Universität Dresden (TUD), Germany. We acknowledge the feedback provided by Prof. Dr. Jürgen Pretzsch (TUD, Germany) on the earlier version of this paper. Thanks also due to Dr. A.H.M. Ali Reza (Texas Tech University, USA) and Mr. Shifath A. Munim (Khulna University, Bangladesh) for providing us with some useful information, and to Dr. Monirul H. Khan (Jahangirnagar University, Bangladesh) for providing us with the consent to use a few of his photographs. We greatly appreciated the valuable comments and feedback provided by the anonymous reviewer and cooperation from Stephen Aitken, Managing Editor.

\section{References}

Ahsan, M.F., and M.A. Saeed. 2009. Bostami turtle no longer endemic only to Bangladesh. Tigerpaper (Bangkok) 36, no. 2: 29-32.

Ahsan, M.F., M.N. Haque, and C.M. Fugler. 1991. Observations on Aspideretes nigricans, a semidomesticated endemic turtle from eastern Bangladesh. Amphibia-Reptilia 12: 131-6.

Anthwal, A., R.C. Sharma, and A. Sharma. 2006. Sacred groves: traditional way of conserving plant diversity in Garhwal Himalaya, Uttaranchal. The Journal of American Science 2: 36-43.

Appanah, S., and L. Ratnam. 1992. The importance of forest biodiversity to developing countries in Asia. Journal of Tropical Forest Science 5: 201-15.

ASB. 2006. Banglapedia: national encyclopedia of Bangladesh. Dhaka: Asiatic Society of Bangladesh (ASB), http:// www.banglapedia.org/.

Berkes, F. 1999. Sacred ecology: traditional ecological knowledge and resource management. London: Taylor and Francis.

Bhagwat, S.A., and C. Rutte. 2006. Sacred groves: potential for biodiversity management. Frontiers in Ecology and the Environment 4: 519-24.

Devereux, P. 2000. The sacred place: the ancient origins of holy and mystical sites. London: Cassell.

FAO. (2005). Global forest resources assessment 2005, FAO Forestry Paper 147. Rome: Food and Agriculture Organization of the United Nations (FAO).

Islam, N., M. Ameen, and A. Nishat. 2000a. Red book of threatened amphibians and reptiles of Bangladesh. Dhaka: IUCN Bangladesh.

Islam, N., M. Ameen, and A. Nishat. 2000b. Red book of threatened mammals of Bangladesh. Dhaka: IUCN Bangladesh. 
Islam, N., M. Ameen, and A. Nishat. 2000c. Red book of threatened birds of Bangladesh. Dhaka: IUCN Bangladesh.

Khan, M.L., S. Menon, and K.S. Bawa. 1997. Effectiveness of the protected area network in biodiversity conservation: a case-study of Meghalaya state. Biodiversity and Conservation 6: 853-68.

Mukul, S.A., and S.A. Quazi. 2009. Communities in conservation: changing protected area management and enhanced conservation in Bangladesh. In Proceedings of the international conference
'The Future of Forests in Asia and the Pacific: Outlook for 2020', 143-59. Chiang Mai, Thailand: FAO-RAP.

Swamy, P.S., M. Kumar, and S.M. Sundarapandian. 2003. Spirituality and sacred groves in Tamil Nadu, India. Unasylva 54: 53-7.

WRI. 2009. Earth trends: the environmental information portal. Washington, DC: World Resources Institute (WRI). http://earthtrends.wri.org.

Zarruq, A., Z. Istrabadi, and H.Y. Hanson. 2008. The principles of Sufism. Bristol: Amal Press. 